\title{
Islamic Jurisprudence for Diversity: From Theological-Normative Reason to Progressive Contextual Reasoning
}

\author{
Ngainun Naim
}

\begin{abstract}
Islamic Jurisprudence for Diversity: From Theological-Normative Reason to Progressive Contextual Reasoning. The reality of Indonesian society is a multicultural society. Therefore, religious understanding and toleration to differences and diversity is necessary to be developed in order to create peace and harmony in the social life. This paper aims to explore the concept of Islamic Jurisprudence in the context of social diversity. This concept is important because the old fiqh concept resting on normative-theological reasonings needs to be reconstructed and replaced with contextual-progressive ones. The changes in the fiqh epistemology from normative-theological to contextual-progressive reasonings are carried out through adaptation to principles of Maqâshid al-Sharîah (basic aims of religious provisions) which are contextualized according to the social growth. The new model of fiqh constructed through combination of religious teachings and social development is expected to make a valuable contribution to the establishment of peace and harmony among all elements of Indonesia society.
\end{abstract}

Keywords: fiqh of diversity, multicultural, society

\begin{abstract}
Abstrak: Fikih Kebinekaan: dari Nalar Teologis-Normatif Menuju Kontekstual Progresif. Realitas masyarakat Indonesia adalah masyarakat multikultural. Oleh sebab itu, pemahaman keagamaan yang toleran terhadap perbedaan dan keanekaragaman penting ditumbuhkembangkan agar tercipta kehidupan yang harmonis di tengah masyarakat. Realitas masyarakat Indonesia adalah masyarakat multikultural. Tulisan ini bertujuan untuk mengeksplorasi konsep fikih Islam dalam konteks keragaman sosial. Konsep ini penting karena konsep fikih lama yang bersandar pada penalaran normatif-teologis perlu direkonstruksi dan diganti dengan pemikiran kontekstual-progresif. Perubahan dalam epistemologi fikih dari penalaran normatif-teologis ke kontekstual-progresif dilakukan melalui adaptasi terhadap prinsip-prinsip Maqâshid al-Sharîah (tujuan dasar dari ketentuan agama) yang dihubungkan dengan perkembangan masyarakat. Melalui model fikih baru yang dibangun lewat kombinasi ajaran agama dan perkembangan sosial diharapkan dapat memberikan kontribusi yang berharga bagi pembentukan perdamaian dan keharmonisan di antara semua elemen masyarakat Indonesia.
\end{abstract}

Kata Kunci: fikih kebinekaan, masyarakat multikultural 


\section{Introduction}

Islamic law has an important position in the lives of Muslims. This is because Islamic law in its reality has become an inseparable part of Islam. In the long history of Indonesia Muslim, Islamic law has metamorphosed into a living law in the society. ${ }^{1}$ Its existence is bigger and stronger than other aspects of Islamic teachings although, of course, other aspects of the mechanism also have undeniable effects. ${ }^{2}$

Islamic law always grows, develops, and communicates with the dynamics of times. This dialectic change gives the Islamic law a dynamic character where it prevails in places with separate uniqueness which is not always exactly the same as that applied in other areas. ${ }^{3}$

This uniqueness does not just appear. There are historical dynamics and a very long interaction process. The construction of Islamic law that is now part of historical chain speaks and interconnects with one another. Thus, an affort to understand the reality of Islam in this era is essential to be made.

The use of historical information has many benefits in finding out the wider Islamic law. The understanding of historical interest in Islamic law is used to reveal two things. ${ }^{4}$ They are the knowledge of development, tension, repetition, changes in Islamic law and that of the reasons underlying the establishment of a law.

The history of Islamic law in Indonesia has been very long. Some claim that Islamic law already exists as the entry of Islam into Indonesia. Nevertheless, there is a claim that Islamic law is only grown after Islam

${ }^{1}$ M. Noor Harisudin, "Diskursus Fikih Indonesia: dari Living Laws Menjadi Positive Laws", Al-Manahij 10, No. 2, (Desember 2016): p. 179.

${ }^{2}$ Mahsun Fuad, Hukum Islam Indonesia: dari Nalar Partisipatoris hingga Emansipatoris (Yogyakarta: LKiS, 2005), p. 34.

${ }^{3}$ Wael B, Hallaq, The Origins and Evolution of Islamic Law. Vol. 1. (Cambridge University Press, 2005). Timur Kuran. "Islam and Underdevelopment: An Old Puzzle Revisited." Journal of Institutional and Theoretical Economics (JITE)/Zeitschrift für die gesamte Staatswissenschaft (1997): p. 41-71. Nilüfer Göle. "Snapshots of Islamic Modernities." In Multiple Modernities, p. 91-118. (Routledge, 2017). Jonathan AJ Wilson, and Jonathan Liu. "The Challenges of Islamic Branding: Navigating Emotions and Halal." Journal of Islamic Marketing 2, no. 1 (2011): p. 28-42.

${ }^{4}$ Akh. Minhaji, Sejarah Sosial dalam Studi Islam: Teori, Metodologi dan Implementasi (Yogyakarta: SUKA Press, 2013), p. 15-16. 
became an integral part of the life of Indonesian society. The argument that is Islam came to Indonesia is not Islam jurisprudence, but tasawuf Islam. Therefore, Islamic law has not been a part of early Islam. ${ }^{5}$

Apart from many debatable issues, one thing that can not be ignored is that Islamic law is the responsibility of Indonesian people. Even Islamic law is rooted from the culture of Indonesian society. This reality shows that Islamic law has a flexible and elastic character. Nevertheless, the dialectic of Islamic law with the sociocultural example of Indonesian society occurs dynamically. ${ }^{6}$

Islamic law in Indonesia is the norms of law derived from the Islamic Shari'a that grows and develops in the life of society throughout Indonesian history. Visible context of time and space affects each other. Islamic law is then to be the last of the dialectical results taking place intensively between normative Islamic law (shari'ah) and local Indonesian content. ${ }^{7}$

Term Islamic law is, "... the alteration of the term al-fiqh" ${ }^{8}$, because in the context of this article, the forgotten law of Islam is figh itself. This alteration is common when there is a congenital culture dialectic in two different languages, cultures, and structures. In sociolingistic discipline, this phenomenon is called a "lexical transformation". According to Abdillah, the cyclical transformation, “... procedural and established law to use. Thus, the use of Islamic legal terms as a customization of the term al-figh would not be problematic".

${ }^{5}$ R. Michael Feener, and Mark E. Cammack, eds. Islamic Law in Contemporary Indonesia: Ideas and Institutions. Vol. 5. Islamic Legal Studies Program, (2007). Michael Barry Hooker, Islamic Law in South-east Asia. (Oxford University Press, USA, 1984). Robin Bush. "10 Regional Sharia Regulations in Indonesia: Anomaly or Symptom?." Expressing Islam: Religious Life and Politics in Indonesia (2008): p. 174. Mark Cammack, Lawrence A. Young, and Tim Heaton. "Legislating Social Change in An Islamic Society-Indonesia’s Marriage Law." The American Journal of Comparative Law 44, no. 1 (1996): p. 45-73. Harry J. Benda, "Christiaan Snouck Hurgronje and the Foundations of Dutch Islamic Policy in Indonesia." The Journal of Modern History 30, no. 4 (1958): p. 338-347. Irshad Abdal-Haqq, "Islamic Law-an Overview of its Origin and Elements." J. Islamic L. \& Culture 7 (2002): p. 27.

${ }^{6}$ Marzuki Wahid \& Rumadi, Figh Madzhab Negara (Yogyakarta: LKiS, 2001), p. 80-81.

${ }^{7}$ Abdul Halim Barkatullah and Teguh Prasetyo, Hukum Islam Menjawab Tantangan Zaman yang Terus Berkembang (Yogyakarta: Pustaka Pelajar, 2006), p. 68.

${ }^{8}$ Mujiyono Abdillah, Dialektika Hukum Islam \& Perubahan Sosial: Sebuah Refleksi Sosiologis atas Pemikiran Ibn Qayyim al-Jauziyyah (Surakarta: Muhammadiyah University Press, 2003), p. 12. 
In general, jurisprudence is understood as knowledge of the laws of Islamic law concerning human acts in which these traits are detailed. Accordingly, figh or jurisprudence is related to various dimensions of law in Islam life. The Muslim life is not stagnant. It does not always grow and develop dynamically. As Abdillah knows, "Islamic law is not born from emptiness (eksnihilo), in an emptiness (innibilo), some are born in the midst of the struggle of community life in response to the real problems that arise".?

Based on this perspective, jurisprudence can ideally provide answers to every topic launched by the community. ${ }^{10}$ Judging from the historical perspective of his birth, jurisprudence is knowledge as the endeavor of the scholars in providing legal answers on the basis of the actual life in society. This perspective shows that figh is dynamic-contextual manifestatition. This nature makes fiqh to be the foundation of the Muslim community in its long history.

Unfortunately, current facts show that jurisprudence is not always able to perform its ideal role. There are cases where jurisprudence unable to provide legal solutions to topics being launched by the public. ${ }^{11}$

\section{The Development of the Intensified and Complex era of Islamic Jurists and Their Responses}

Thought and accountability has enable Islamic jurists to do various possibilities for the growth and development of society along with the development of the times.

Jurisprudence, thus, is a very dynamic field of science. The dynamic nature of jurisprudence requires an innovative, creative-innovative effort from experts to respond to existing challenges. If not, then figh will be relevant in everyday complex life. When jurisprudence or figh is no longer able to answer, then it has lost its relevance in the application of Islamic life.

\footnotetext{
${ }^{9}$ Mujiyono Abdillah, Dialektika Hukum Islam \& Perubahan Sosial, p. 13.

${ }^{10}$ See Peter Goodrich, "Rhetoric as Jurisprudence: An Introduction to the Politics of legal Language." Oxford J. Legal Stud. 4 (1984): p. 88.

${ }^{11}$ Abdul Wahhab Khallaf, Ushôl al-Fiqh (Kuwait: Dar al-Qalam, 1978), p. 15.
} 
In this perspective, renewal or innovation is important to be made. Renewal is, "... efforts, both individually and collectively in the period and specifically, to assist in the perception and practice of Islam that has been established for the understanding and practice of the new" ${ }^{12}$ Renewal Islamic law can not be separated from the Islam law because it is part of Islam life. Tracing the history pointed to the figure of Ibn Taymiyyah as the one who started the movement of ijtihad. ${ }^{13}$ Conditionpaced of a society in the era of imitation fanatic leads to the rigidity of Islamic law. More explicit implication is Muslim's setback in general. ${ }^{14}$ Exclusive attempts of real fiqh have been done in every age and every place throughout the Islamic world. Renewal is done in an effort to bring fiqh to answer the development of the era. The purpose of Islamic law renewal is to understand Islamic law in a more rational, methodological, modern and actual way. ${ }^{15}$

According to Rofiq, the renewal of Islamic legal law in Indonesia found its momentum in the 1970s, although its tracks could be traced long time ago. Individually, this movement is driven by TM Hasbi AshShidieqy and Hazairin. The Hasbi's press is an important benefit. The idea to make an important contribution to the significance of jurisprudence in the context of national law development, had encouraged Hazairin to initiate the law of bilateral inheritance. The idea of Hazairin ${ }^{16}$ is

${ }^{12}$ Ahmad Rofiq, Pembaharuan Hukum Islam di Indonesia (Yogyakarta: Gama Media, 2001), p. 97.

${ }^{13}$ See about ijtihad, Wael B Hallaq. "Was the Gate of Ijtihad Closed?." International Journal of Middle East Studies 16, no. 1 (1984): p. 3-41; "On the Origins of the Controversy about the Existence of Mujtahids and the Gate of Ijtihad." Studia Islamica 63 (1986): p. 129141. Ihsan Yilmaz. "Ijtihad and Tajdid by Conduct." Turkish Islam and the Secular State, the Gülen Movement. Syracuse, NY: Syracuse University Press. Google Scholar (2003). Abdullah Saeed, "Ijtihad and Innovation in Neo-Modernist Islamic Thought in Indonesia." Islam and ChristianMuslim Relations 8, no. 3 (1997):p. 279-295. Rachel Anne Codd. "A Critical Analysis of the Role of Ijtihad in Legal Reforms in the Muslim World." Arab Law Quarterly 14, no. 2 (1999): p. 112-131.

${ }^{14}$ Abdul Halim Barkatullah, and Teguh Prasetyo. Hukum Islam: Menjawab Tantangan Zaman yang Terus Berkembang: Membahas Perkembangan Hukum Islam, Hukum Keluarga Islam, Hukum Ekonomi Islam, Hukum Pidana Islam (Yogyakarta: Pustaka Pelajar, 2006), p.16.

${ }^{15}$ Abdul Halim Barkatullah and Teguh Prasetyo, Hukum Islam, p. 19.

${ }^{16}$ See Hazairin, Hukum Kekeluargaan Nasional (Jakarta: Tintamas, 1962); Tudjuh Serangkai Tentang Hukum (Jakarta: Tintamas, 1974). 
related to the concept of mawali in the Sunni jurisprudence system. It is an attempt to eliminate the inheritance to the niece from mother into zawî al-arhâm (not inherited) as mentioned in Q.s. al-Nisa 'verse 33. ${ }^{17}$ Other name should be mentioned her is Munawir Sjadzali with his notion "Reaktualisasi Ajaran Islam"18 or Islamic teachings reactualization, Bustanul Arifin through the magazine "Institutional Law of Islam", A. Qodri Azizy through the concept of "Eclectic Law of Indonesia", ${ }^{19}$ and Yudian Wahyudi with the concept of "Fikih Indonesia". ${ }^{20}$

Institutionally, the MUI Fatwa Commission under the leadership of Prof. Ibrahim Hosen seeks Rofiq as a fertile period with its reformation. He started his movement through the study of figh comparative, ush $\hat{u} l$ fiqh comparison, and siyâsah syar'iyah. In addition to MUI, there are many other organizations that also perform Islamic law, such as NU and Muhammadiyah. ${ }^{21}$

Times continue to grow and change. New things come and greet our lives. New variety is present. Islamic law is substantially a dialogical product between revelation and social reality. This kind of perspectives necessitates against the back of the dynamics and suffering is not allowed to occur without the existence of a supporting tool. In this case, the concept of a set of concepts as reference and application for dimension and empirical is very important.

Jurisprudence that can not develop society will lose its relevance in the practice of everyday life. If efforts are not made, the jurisprudence will

${ }^{17}$ Abdul Halim Barkatullah and Teguh Prasetyo, Hukum Islam, p. 171. Agus Moh. Najib, Pengembangan Metodologi Fikih Indonesia dan Kontribusinya bagi Pembentukan Hukum Nasional (Jakarta: Kementerian Agama RI, 2011), p. 57-85.

${ }^{18}$ Asmawi Mahfudz, Pembaruan Hukum Islam (Yogyakarta: Teras, 2010), p. 225. See also Munawir Sjadzali. Polemik Reaktualisasi Ajaran Islam. (Jakarta: Pustaka Panjimas, 1988); Ijtihad Kemanusiaan (Jakarta: Paramadina, 1997).

${ }^{19}$ Ahmad Qodri Abdillah Azizy, Eklektisisme Hukum Nasional: Kompetisi Antara Hukum Islam dan Hukum Umum (Yogyakarta: Gama Media, 2002).

${ }^{20}$ Yudian Wahyudi, Ushul Fikih Versus Hermeneutika: Membaca Islam dari Kanada dan Amerika (Yogyakarta: Pesantren Nawasea Press, 2007); Maqâshid Syari'ah dalam Pergumulan Politik: Berfilsafat Hukum Islam dari Harvard ke Sunan Kalijaga (Yogyakarta: Nawesea, Pesantren Nawesea Press, 2007).

${ }^{21}$ Ah Halid Alkaf, Quo Vadis Liberalisme Islam Indonesia (Jakarta: Kompas, 2011), p. 227. Ahmad Rofiq, Pembaharuan Hukum Islam Indonesia, p. 172. 
lose its contextualisation in the dynamics of the times. In such conditions, a clean effort of Islamic law is required. The renewal of Islamic law is an attempt by Muslim scholars and intellectuals to enable Islamic law to realize the plight of Islamic life in the world and the hereafter. Efforts made by Islamic law are always actual-contextual in harmony with the dynamics of the development of society. ${ }^{22}$

This renewal or improvement creates many different perspectives among Muslims. The actual difference is not in the substantial content, but it is at the level of interpretation. Thus, a renewal is a must. It means that what needs to be renewed is actually the interpretation of islamic teachings, but not the values or principles in Islam which can be in harmony with the dynamics of the times.

Making changes and improving the interpretation of Islamic law needs to be continually done. One of the important factors to be appreciated is the Figh of Diversity. This paper discusses the significance of the jurisprudence of diversity, the multicultural reality of Indonesia, and the epistemological offer for the development of jurisprudence.

\section{Multicultural Indonesian Reality}

Multiculture is an integral part of Indonesian image. There are many ethnics, religions, cultures, linguistics and unique characters. The reality of this diversity has been an integral part of Indonesia's long history from now on. ${ }^{23}$

Religions that are present and become part of the life of Indonesian society are indeed the empirical evidence of the diversity that exists in

${ }^{22}$ Iskandar Usman, Istihsan dan Pembaharuan Hukum Islam (Jakarta: Raja Grafindo Persada, 1994), p. 116-117.

${ }^{23}$ About multicultural see Ruslan Ibrahim, "Pendidikan Multikultural: Upaya Meminimalisir Konflik dalam Era Pluralitas Agama." EL TARBAWI 1, no. 1 (2008): p. 115-127. Andik Wahyun Muqoyyidin. "Membangun Kesadaran Inklusif-Multikultural untuk Deradikalisasi Pendidikan Islam." Jurnal Pendidikan Islam 2, no. 1 (2012). Moh. Dahlan, "Paradigma Ushûl Fikih Multikultural di Indonesia." Ijtihad: Jurnal Wacana Hukum Islam dan Kemanusiaan 12, no. 1 (2012): p. 1-19. Lutfi Rahmatullah. "Eksistensi Hukum Islam di Tengah Keragaman Budaya Indonesia (Perspektif Baru Sejarah Hukum Islam dalam Bingkai Dialektika Nilai-nilai Syari'ah dan Budaya)." Al-Manahij: Jurnal Kajian Hukum Islam 10, no. 1 (2016): p. 63-82. Ngainun Naim, "Membangun Kerukunan Masyarakat Multikultural." Harmoni 15, no. 1 (2016): p. 203-213. 
Indonesia. Indonesian diversity is very high, even the highest in the world. In addition, Indonesia also has regional languages, cultures, and religions. The reality of this diversity is supported by a very rich history of diversity This experience is a very important social manifestation. ${ }^{24}$

The reality of Indonesian Islam also has a similar portrait. The face of Indonesian Islam is not singular. There are so many features, varieties, and expressions of Indonesian Islam. Each uses dynamic dialectic. The relationship between different faces of Islam is different from time to time. ${ }^{25}$ According to Ziauddin Sardar, plurality and diversity are not merely sociological realities. Plurality and diversity should instead be a pillar of Islam. ${ }^{26}$ This is what plurality and diversity mean as part of Islamic teachings.

In fact, it is not easy to map carefully the objectivity of Islam in Indonesia. This is due to its complexity. The categorization done by scientists is a simplified way to be understood, read, and analyzed to be more complex in a complex reality.

A very important aspect to continue growing in the midst of the society is to build a wiser lifestyle. An important effort to be done is to socialize the understanding of the community. Society needs to be given an intensive message in order to have maturity in religion. Maturity in religion will have a wide influence on the maturity of many other areas of life. ${ }^{27}$ Good understanding is expected to foster consciousness. Awareness as the fruit of religious maturity requires various instruments to discuss. The field of Islamic law is one of the important instruments.

Islamic law thought is now facing big challenges. One of them is how Islamic law can best serve multicultural Indonesians. ${ }^{28}$ Most Indonesian

${ }^{24}$ Bernard Adeney-Risakotta (ed.), Mengelola Keragaman di Indonesia, Agama dan Isu-isu Globalisasi, Kekerasan, Gender, dan Bencana di Indonesia (Bandung-Yogyakarta: Mizan bekerjasama dengan ICRS, 2015), p. 23.

${ }^{25}$ Mujamil Qomar, Tradisi-Tradisi Kreatif Pemikiran Islam Indonesia (Tulungagung: IAIN Tulungagung Press, 2015), p. 3 ..

${ }^{26}$ Ziauddin Sardar, Jihad Intelektual, Merumuskan Parameter-Parameter Sains Islam, trans. A.E. Priyono, (Surabaya: Risalah Gusti, 1998), p. 35.

${ }^{27}$ Tobroni, Relasi Kemanusiaan dalam Keberagamaan (Mengembangkan Etika Sosial Melalui Pendidikan (Bandung: Karya Putra Darwati, 2012), p. 77.

${ }^{28}$ Raihani, Creating Multicultural Citizens: A Portrayal of Contemporary Indonesian Education 
Islamic legal thinkers talk about how to apply Islamic law in Indonesia only to Muslims. Contextualizing efforts of Islamic law with the culture and reality of Indonesian society will produce more articulative products suitable with Indonesian people. ${ }^{29}$ This is not an easy challenge. To be able to contribute is crucial for the religious life in Indonesia. In this case, renewing a jurisprudence or figh becomes a necessity. Jurisprudence of diversity is an important benefit for detail.

\section{A Shift of Epistemological Aspects}

The emergence of various thoughts in relation to the figh/ jurisprudence development needs to be addressed in a critical-constructive way. Such thinking on one hand is an attempt to present a more actual and contextual jurisprudence. ${ }^{30}$ Nevertheless, history will prove that only ideas that are in harmony with the dynamics and needs of society that continues to grow and develop. Many ideas appear, but only a few survive. The rest lost in the flow of history.

One of the interesting ideas to be appreciated is the Fiqh of Diversity. This term is not raised specifically by a particular person. This idea appears to be the title of a book that brings together the thoughts, ideas, and articulations of its authors. ${ }^{31}$

The combination of the words "Jurisprudence/fiqh" and "Diversity" creates a special meaning. Diversity comes from the word "bhineka" which means diverse, varied. Thus, the fiqh of diversity in this sense is the jurisprudence which regulates the social relations of religion. The

(London and New York: Routledge, 2014), p. 1.

${ }^{29}$ Agus Moh. Najib, Pengembangan Metodologi Fikih Indonesia, p. 5-6.

${ }^{30}$ About actual and contextual jurisprudence, see Abraham Udovitch, "Islamic Law and the Social Context of Exchange in the Medieval Middle East." History and Anthropology 1, no. 2 (1985): p. 445-465. Anver M. Emon, "Conceiving Islamic Law in A Pluralist Society: History, Politics and Multicultural Jurisprudence." Sing. J. Legal Stud. (2006): p. 331. Willis Jenkins, "Islamic Law and Environmental Ethics: How Jurisprudence (Ushûl Al-Fiqh) Mobilizes Practical Reform." Worldviews: Global Religions, Culture, and Ecology 9, no. 3 (2005): p. 338-364. I. K. A. Howard, "Mut'a Marriage Reconsidered in the Context of the Formal Procedures for Islamic Marriage." Journal of Semitic Studies 20, no. 1 (1975): p. 82-92.

${ }^{31}$ Wawan Gunawan Abd. Wahid, dkk (Eds.), Fikih Kebinekaan: Pandangan Islam Indonesia tentang Umat, Kewargaan, dan Kepemimpinan non-Muslim (Bandung: Mizan bekerja sama dengan Maarif Institute, 2005). 
name of fiqh of true diversity is not without consequences. The terms contain something different from the construction of Jurisprudence in general. One different aspect is epistemology.

One important aspect to note is the epistemological aspect. One of the definitions of epistemology is that the theory of knowledge that discusses knowledge and ability, and they also can not be directly through the conclusion of the mind". ${ }^{32}$ Epistemology becomes one of the branches of philosophy. The scope is very broad, ranging from genuineness, nature, structure, type, method, none, validity, kind, limit, support, objective, basic, assumption, nature, responsibility and knowledge scope. ${ }^{33}$

In revealing privacy, epistemology occupies a very important role. The role of epistemology is very significant in formulating, composing, and developing science. In this case, the knowledge of figh is also based on epistemology. ${ }^{34}$

According to Danusiri, by quoting Al-Syatibi, ${ }^{35}$ there are four mindsets in the lesson of Nash. First, the mind of Zhâhiriyyat. These substantive thought patterns are syarak which means that they can only be known from explicit written text. Consequently, in determining the law there is no assistance outside the texts. Nevertheless, the group received the takwil. His Zhâhir means that it can only be denied by other nash of the same type of zhâhir. In this perspective, the real takwil used is also able to position them as a group of Zhâhiriyyat. ${ }^{36}$

Second, the mindset of Bâthiniyyat is different from the Zhâhiriyyat that holds the text of nash as well as contextual meaning. This mindset can be categorized as liberal that does not use the rules in the study of ushîl figh. It departs from the word that in every born, there is an inner

32 Ahmad Hasan Ridwan dan Irfan Safrudin, Dasar-dasar Epistemologi Islam (Bandung: Pustaka Setia, 2011), p. 11-12.

${ }^{33}$ Mujamil Qomar, Epistemologi Pendidikan Islam, dari Metode Rasional hingga Metode Kritik (Jakarta: Erlangga, 2006), p. 5.

${ }^{34}$ Mujamil Qomar, Epistemologi Pendidikan Islam, p. ix-x.

${ }^{35}$ Abu Ishaq al-Syatibi, al-Muwafaqat $f i$ Ushul al-Ahkam (Bayrut: Dar al-Kitab al-'Ilmiyyah, 2002).

${ }^{36}$ Danusiri, "Epistemologi Syara", dalam Noor Ahmad, dkk., Epistemologi Syara': Mencari Format Baru Figh Indonesia (Yogyakarta: Pustaka Pelajar, 2000), p. 49-50. 
dimension, and in every revelation coming down, there is a takwil. This mindset describes the teachings of Islam. ${ }^{37}$

The third is the contextual mindset. Contextual meaning is broad enough. Al-Syatibi describes the contextual views as the viewsof the group who prefer to make qiyâs or analogy. This group prioritizes the meaning of the text from the text itself. They seek meaning behind the text which $t$ is not contradictory to the text unless the text pronounce of its absolute meaning that shows unity intact.

The meaning between text and context is very likely different, even may contradictory. In these conditions, groups of contextual thinking prefer contextual meaning. The reason is for the everyone's benefit. Another possible step in case of trouble or repetition is to seek new meaning because a mujtahid can not be required to take it textually. ${ }^{38}$

The fourth is a combination of textual and contextual views. This group emerges as a mature intellectual group. Danusiri points out that the method developed by this group is the same as the contextualist group, one of which is in fact al-mutáamiqan fi al-qiyâs, and Zhâhiriyyat with the deed that the Syâri '(God and Apostle) which presents his Syara, with respect to 'adiyat or' ibâdiyat. Each of which has the original intention (ashliyyat) and its accompanying intention (tabi iyyat). ${ }^{39}$

Merytics set of concepts as a reference in the implementation of Qur'anic and Hadith texts is not an easy task. It takes a variety of backgrounds and other requirements for the concept to be formulated to have the ability to be actualized in the context of everyday life. One that is required is 'critical reading'. Critically-constructive readings are highly significant that the dynamics which occur remain in the corridor of science and they have a normative-religious basis.

A contextual-progressive perspective or a textual and contextual combined mindset is more important to be expressed as an endeavor to bring fiqh that is in harmony with the dynamics of the times.

\footnotetext{
${ }^{37}$ Danusiri, "Epistemologi Syara”, p. 51-54.

38 Danusiri, "Epistemologi Syara”, p. 56-57.

39 Danusiri, "Epistemologi Syara”, p. 60-61.
} 
Jurisprudence does not exist in an empty space apart from reality. Precisely, the jurisprudence becomes the solution to the gallery on the factual level. If this is done then jurisprudence will find a significant role as a solution to the law discussed by Muslims. Jurisprudence is one of the efforts to bring figh which is able to respond to the moment of the development of the times.

Indeed, there are enough intellectuals who offer various aspects of Islam. One of the Islamic intellectuals who has an important role in the context of presenting progressive-contextual epistemology is M. Amin Abdullah. His thought in this context attracts the attention represented by strengthening the flow of fundamental Islamic groups.

After the fall of Soeharto reign, the development of democracy was quite encouraging in Indonesia. Even Indonesia is called as one of the most democratic Muslim countries in the world. However, the development of this democracy must deal with another quite disturbing phenomenon, namely the growth of fundamentalist groups. Such groups in their actions are much at odds with the values and principles of democracy. ${ }^{40}$

The main groups that exist in Indonesia are to instill ideology continuously in various aspects of life. State Islamic Religious Colleges (PTKIN) also becomes a land for the distribution and seedling of fundamentalist ideology. ${ }^{41}$

One type of this group can be identified through the way of reading religious texts. This group rigidly interpretive the text and leave no range of opportunities to explore. Creative-innovative intellectual ideas do not get adequate places. They only understand the text in real terms.

Criticism of the existence of the fundamentalist group then elicits creative intellectual work. Jurisprudence is a manifest manifestation of the user in responding to the challenges of life of the current plural-

${ }^{40}$ Noorhaedi Hasan, "Religious Diversity and Blasphemy Law: Understanding Growing Religious Conflict and Intolerance in Post-Suharto Indonesia”, Al-Jamiah 55, No. 1, (2017 M/1438 H): p. 106.

${ }^{41}$ Toto Suharto and Ja'far Assagaf, "Membendung Arus Paham Keagamaan Radikal di Kalangan Mahasiswa PTKIN", Jurnal Al-Tahrir 14, No. 1, (Mei 2014): p. 159-165. 
multicultural society. The idea of Jurisprudence of Diversity, attention, interesting to be explored further to mature and find the momentum of its development.

\section{Intellectual Works}

Jurisprudence of diversity (fiqh of diversity) is an intellectual effort that has a significant role in providing jurisprudence that is in harmony with the dynamics of the development of Indonesian society. As a country with a high degree of diversity, the monolithic perspective of fiqh is certainly not in harmony with reality. Precisely it is because the phenomenon of Jurisprudence is important to be explored, disseminated and offered to various layers of society. Through these various possibilities, it is expected that Figh of Diversity will be better known, appreciated, and on dating will increasingly find an increasing mature formula.

The idea of Jurisprudence of Diversity needs an established epistemological foundation. There are several aspects of epistemology that are of concern. First, epic jurisprudence needs to know the orientation shift. The old illahiyah-theological orientation remains to be done, but needs to be enriched with other dimensions, namely the dimensions of insâniyyahhumanistic and 'alamiyah-cosmological. Second, the epistemology that is suitable for the life of Islam now or the future is operative-burhâni (rational-empirical). This epistemological feature includes a re-concept of Islamic theology and Islamic ethics from normative-personality to social nuance. From the metaphysical to the empirical-scientific nuances. ${ }^{42}$

Jurisprudence of diversity will only be limited to the focus which then disappears if not followed up with intellectual work seriously. According to M. Amin Abdullah, the development of Jurisprudence of diversity is only possible if the Maqâshid al-Syar'iyyah is contemporary. ${ }^{43}$

${ }^{42}$ Muhammad Azhar, "Epistemologi Islam Kontemporer Sebagai Basis Fikih Kebinekaan", dalam Wawan Gunawab Abd. Wahid, dkk., (eds.), Fikih Kebinekaan: Pandangan Islam Indonesia tentang Umat, Kewargaan, dan Kepemimpinan Non-Muslim (Bandung: Mizan, 2015), p. 104-105.

${ }^{43}$ Salah satu tulisan yang mengelaborasi konsep mashlahah adalah Abdul Hamid, "Aplikasi Teori Mashlahah (Maslahat) Najm Al-Din Al-Thûfî dalam Penyelesaian Sengketa Perjanjian Bisnis di Bank Syariah", Jurnal Al-Adalah 12, No. 4, p. 729-742. 
Contemporary understanding not only covers an internal scope but also more comprehensive and universal limitation. The Maqâshid style, thus, is not only on the aspect of safeguarding (hifzh), but shifting to development (tanmiyah). The old understanding which was only to protect the human dignity of Muslims (hifzh al-irdh) shifted and expanded into universal frequency. This kind of effort displays M. Abdullah as an endeavor to be used to provide benefits for the future. ${ }^{44}$

Maqâshid also needs to get a more contextual meaning to get more expanded interpretation. Some comparisons of Maqâshid offered by Syamsul Anwar include: (1) man in the dimension of the environment as an individual (within his own environment). (2) Humans in the environmental dimension as family members (human in family environment). (3) Humans in the environmental dimension as members of society (human in social environment, including state). (4) Humans in the dimensions of their environment as God's creatures with other God in human nature. ${ }^{45}$

According to M. Amin Abdullah, one important aspect in the idea of Jurisprudence is the mindset. It is important because it becomes the basis of paradigm. ${ }^{46}$ An important paradigm is to read the position of an idea or thought and enabling its development. One aspect that is needed is to develop a paradigm, that is, the paradigm of thinking can turn into a non-critical belief or habit of thinking about complex dynamics. Portrait of such paradigm is developed within among Indonesian Islam. In the midst of the multicultural society of Indonesia, this paradigm is less compatible.

The paradigm formula that does not fall into confidence is not easy

${ }^{44}$ M. Amin Abdullah, "Memaknai Al-Rujû̀ Ilâ Al-Qur'ân wa Al-Sunnah, dari Qirâa'ah Taqlîdiyyah ke Târîkhiyyah-Maqâshidiyyah", in Wawan Gunawan Abd. Wahid, dkk (Eds.), Fikih Kebinekaan: Pandangan Islam Indonesia tentang Umat, Kewargaan, dan Kepemimpinan non-Muslim (Bandung: Mizan bekerja sama dengan Maarif Institute, 2005), p. 68-69.

${ }^{45}$ Syamsul Anwar, "Maqâshid al-Syarîah dan Metodologi Ushul Fikih", in Wawan Gunawan Abd. Wahid, dkk (Eds.), Fikih Kebinekaan: Pandangan Islam Indonesia tentang Umat, Kewargaan, dan Kepemimpinan non-Muslim (Bandung: Mizan bekerja sama dengan Maarif Institute, 2005), p. 78.

46 Thomas S. Kuhn, The Structure of Scientific Revolution (Chicago: The University of Chicago Press, 1970). 
to find. Experts doing these important things offer important formulas to read and appreciate critically. M. Amin Abdullah's offer of a contextualprogressive paradigm (Tarikhiyyah-Maqâshiddiyyah) is one of the favorable paradigms to respond negatively-constructively. The adult contextualprogressive paradigm provides insight into various aspects of life. The cornerstone of this paradigm is to prioritize the main religious objectives (maqâshid al-syariah). ${ }^{47}$

The paradigm offered by M. Amin Abdullah uses Systematic Approach. This literature is adapted from Jasser Auda's thinking. There are six features designated by M. Amin Abdullah as a mode of thought and a philosophical foundation that is important for Muslim thinkers in developing thought. These six features also serve for the operationalization of minds and processes that are practical for the current Muslim era.

The first feature is a feature of cognitive (al-idrâkiyyah, cognition). This feature is important because there is a tendency to equate religious scholars between 'Revelation' and 'Cognition' of revelation. In this context, fiqh, which is claimed as the 'divine knowledge', needs to be shifted to the field of knowledge 'cognition (understanding ratio) of man against scientific knowledge'. Understanding these features is believed to be able to answer cognition acute problems in understanding and religious faith, between the 'absolute' and the 'relativity'.

The second feature is the comprehensiveness (al-Kulliyyah, wholeness). This feature seeks to remedy some of classic Ushîl Fiqh which tends to be reductionist and atomistic. At the operational level, the comprehensive principle is implemented through 'thematic interpretation' which is not only limited to the verses of the law, but it involves the whole paragraph of Al-quran as well. Comprehensiveness is a material consideration in deciding Islamic law comprehensively.

The third feature is the openness (al-Infitâhiyyah, Openness). This feature has a highly strategic function, i.e expand the meaning of custom or 'urf. 'Urf in this context not only of Arab customs which emphasize times and eat (spot) as conceived, but rather on the world view and depth

${ }^{47}$ M. Amin Abdullah, "Memaknai”, p. 49. 
of knowledge a faqîh, in addition to space, time and region. Competence a faqîh is very important because it will bring consequences to the views of Islamic law, namely: (a) reduce the literalism of Islamic law; and (b) open system of Islamic law to progress in the natural sciences, social and cultural aspects.

The fourth feature is the hierarchy of interrelated (al-Harakiriyyah al-Mu'tamadah Tabadulliyan, interrelated hierarchy). This feature works on repair ing two-dimensional maqâshid sharîa, namely the improvement of the coverage area including maqâshid and repair area covering maqâshid range.

The fifth feature is the multi-dimensionality (Ta'addud al-Ab'ad; Multidimensionality). This feature, as affirmed by M. Amin Abdullah, when combined with maqâshid approach it is believed to offer a solution to the dilemma of the arguments to the contrary. Two contradictory propositions can be combined in a new context, namely maqâshid. This conciliation pattern has implications for the flexibility of Islamic law in the face of contemporary problems of a complex problem.

The sixth feature is the main purpose or purposiveness. This feature is intended to primary sources (Quran and Hadith) and sources of rational (qiyâs, Istihbsan, and others). ${ }^{48}$

M. Amin Abdullah's thought is just one of many ideas to make diversity jurisprudence have a solid epistemological basis. Another person who also has a diversity of thought about Jurisprudence is Syamsul Anwar. If M. Amin Abdullah puts more emphasis on the philosophy of science perspective, Syamsul Anwar gives a perspective of Ushûl Fiqh.

Syamsul Anwar explains that students of Ushûl Fiqh mention five kinds of fundamental protection, namely: (1) the protection of the religiosity, (2) the protection of life, (3) protection of sense, (4) protection of offspring, and (5) protection of wealth. This protection concept needs to be further developed to suit the dynamics and developments. If you stick with the concept formulated by the students of Ush $\hat{u} l$ Figh hence the pre-modern concept of essential poblem (dharûriyyah) will lose its

${ }^{48}$ M. Amin Abdullah, "Memaknai”, p. 62-64. 
relevance and is not able to answer the needs of contemporary society.

One of the drawbacks of the above five concepts of protection is the emphasis on the human aspect as individuals. In fact, people today can not be seen only as individuals. Humans are not a separate part of a larger community. Accordingly, Syamsul Anwar offers serious benefits development that includes aspects of protection, empowerment and human development in a four-dimensional sphere. These four dimensions are:

1. Man in the environmental dimension of its existence as an individual (in the environment itself).

2. Man in the environmental dimension of its existence as a member of the family (man in the family).

3. Man in the environmental dimension of existence as a member of society (human beings in community and social environment, including the state).

4. Environmental and human dimensions of God's existence as being more in the nature (human beings in the natural environment).

According to Syamsul Anwar, the four dimensions of human existence require some protection, empowerment and or development. The four beneficiaries which are essentially carried by al-Syâthibî can be distributed into one or more of the four environmental presence. ${ }^{49}$

\section{Conclusion}

Jurisprudence is the real field of study which tends to be very dynamic. This is because jurisprudence is directly related to the daily lives of Muslims. Life in the modern era is experiencing tremendous complex development. Consequently, a variety of new problems emerging. At this point Jurisprudence challenged to respond and answer to existing problems.

Jurisprudence diversity is an important endeavor to be constructively appreciated. It is actually an attempt to provide answers to the various problems of social relationships among Indonesian multicultural nation.

${ }^{49}$ Syamsul Anwar, "Maqâshid al-Syarîah dan Metodologi Ushûl Fikih", p. 77-78. 
Conflicts and violence among Muslims require serious solutions. Jurisprudence of harmony expected to be-one-solution in creating a harmonious life.

Harmony jurisprudence idea still needs serious reconstruction and work to be better established. In addition to the dimensions of epistemology, ontology and axiology dimension must also be identified by well-established perspectives so that this idea can get widespread public response. The response for the sake of response is essentially an attempt to test the existence of an idea: survive or disappear is swallowed by the tide of history.

\section{Bibliography}

Abdul Halim Barkatullah, and Teguh Prasetyo. Hukum Islam: Menjawab Tantangan Zaman yang Terus Berkembang: Membahas Perkembangan Hukum Islam, Hukum Keluarga Islam, Hukum Ekonomi Islam, Hukum Pidana Islam. Yogyakarta: Pustaka Pelajar, 2006.

Abdillah, Mujiyono. Dialektika Hukum Islam \& Perubahan Sosial: Sebuah Refleksi Sosiologis atas Pemikiran Ibn Qayyim al-Jauziyyah. Surakarta: Muhammadiyah University Press, 2003.

Adeney, Bernard-Risakotta (ed.), Mengelola Keragaman di Indonesia, Agama dan Isu-isu Globalisasi, Kekerasan, Gender, dan Bencana di Indonesia. Bandung-Yogyakarta: Mizan bekerjasama dengan ICRS, 2015. Alkaf, Ah Halid. Quo Vadis Liberalisme Islam Indonesia. Jakarta: Kompas, 2011.

Azizy, Ahmad Qodri Abdillah. Eklektisisme Hukum Nasional: Kompetisi Antara Hukum Islam dan Hukum Umum. Yogyakarta: Gama Media, 2002.

Abd. Wahid, Wawan Gunawan dkk (Eds.), Fikih Kebinekaan: Pandangan Islam Indonesia tentang Umat, Kewargaan, dan Kepemimpinan nonMuslim. Bandung: Mizan bekerja sama dengan Maarif Institute, 2005. Abdullah, M. Amin. "Memaknai Al-Rujû̀ Ilâ Al-Qur'ân wa Al-Sunnah,dari Qirâah Taqlîdiyyah ke Târîkhiyyah-Maqâshidiyyah", in Wawan Gunawan Abd. Wahid, dkk (Eds.), Fikih Kebinekaan: Pandangan Islam Indonesia tentang Umat, Kewargaan, dan Kepemimpinan nonMuslim. Bandung: Mizan bekerja sama dengan Maarif Institute, 2005. 
Anwar, Syamsul. "Maqâshid al-Syarîah dan Metodologi Ushul Fikih", in Wawan Gunawan Abd. Wahid, dkk (Eds.), Fikih Kebinekaan: Pandangan Islam Indonesia tentang Umat, Kewargaan, dan Kepemimpinan nonMuslim. Bandung: Mizan bekerja sama dengan Maarif Institute, 2005. Azhar, Muhammad. "Epistemologi Islam Kontemporer Sebagai Basis Fikih Kebinekaan", in Wawan Gunawan Abd. Wahid, dkk., (eds.), Fikih Kebinekaan: Pandangan Islam Indonesia tentang Umat, Kewargaan, dan Kepemimpinan Non-Muslim. Bandung: Mizan, 2015.

Bush, Robin. "10 Regional Sharia Regulations in Indonesia: Anomaly or Symptom?." Expressing Islam: Religious Life and Politics in Indonesia (2008): 174.

Benda, Harry J. "Christiaan Snouck Hurgronje and the Foundations of Dutch Islamic Policy in Indonesia." The Journal of Modern History 30, no. 4 (1958): 338-347.

Cammack, Mark, Lawrence A. Young, and Tim Heaton. "Legislating Social Change in An Islamic Society-Indonesia's Marriage Law." The American Journal of Comparative Law 44, no. 1 (1996): 45-73.

Codd, Rachel Anne. "A Critical Analysis of the Role of Ijtihad in Legal Reforms in the Muslim World." Arab Law Quarterly 14, no. 2 (1999): 112-131.

Dahlan, Moh. "Paradigma Ushûl Fikih Multikultural di Indonesia." Ijtihad: Jurnal Wacana Hukum Islam dan Kemanusiaan 12, no. 1 (2012): 1-19. Danusiri, "Epistemologi Syara", in Noor Ahmad, dkk., Epistemologi Syara': Mencari Format Baru Fiqh Indonesia. Yogyakarta: Pustaka Pelajar, 2000.

Emon, Anver M. "Conceiving Islamic Law in A Pluralist Society: History, Politics and Multicultural Jurisprudence." Sing. J. Legal Stud. (2006): 331.

Göle, Nilüfer. "Snapshots of Islamic Modernities." In Multiple Modernities, Routledge, 2017.

Irshad Abdal-Haqq. Islamic Law-an Overview of its Origin and Elements." J. Islamic L. \& Culture 7 (2002): 27.

Fuad, Mahsun. Hukum Islam Indonesia: dari Nalar Partisipatoris hingga Emansipatoris. Yogyakarta: LKiS, 2005. 
Feener, R. Michael, and Mark E. Cammack, eds. Islamic Law in Contemporary Indonesia: Ideas and Institutions. Vol. 5. Islamic Legal Studies Program, 2007.

Goodrich, Peter. "Rhetoric as Jurisprudence: An Introduction to the Politics of legal Language.” Oxford J. Legal Stud. 4 (1984): 88.

Hooker, Michael Barry. Islamic Law in South-east Asia. Oxford University Press, USA, 1984.

Hamid, Abdul. "Aplikasi Teori Mashlahah (Maslahat) Najm Al-Din Al-Thûfî dalam Penyelesaian Sengketa Perjanjian Bisnis di Bank Syariah", Jurnal Al-Adalah 12, No. 4, 729-742.

Harisudin, M. Noor. "Diskursus Fikih Indonesia: dari Living Laws Menjadi Positive Laws", Al-Manahij 10, No. 2, (Desember 2016): 179.

Hallaq, Wael B. "Was the Gate of Ijtihad Closed?." International Journal of Middle East Studies 16, no. 1 (1984): 3-41.

. On the Origins of the Controversy about the Existence of Mujtahids and the Gate of Ijtihad." Studia Islamica 63 (1986): 129-141.

Hazairin. Hukum Kekeluargaan Nasional. Jakarta: Tintamas, 1962 . Tudjuh Serangkai Tentang Hukum. Jakarta: Tintamas, 1974.

Hasan, Noorhaedi. "Religious Diversity and Blasphemy Law: Understanding Growing Religious Conflict and Intolerance in PostSuharto Indonesia”, Al-Jamiah 55, No. 1, (2017 M/1438 H): p. 106. Howard, I. K. A. "Mut'a Marriage Reconsidered in the Context of the Formal Procedures for Islamic Marriage." Journal of Semitic Studies 20, no. 1 (1975): 82-92.

Ibrahim, Ruslan. "Pendidikan Multikultural: Upaya Meminimalisir Konflik dalam Era Pluralitas Agama.” EL TARBAWI 1, no. 1 (2008): 115-127.

Jonathan AJ Wilson, and Jonathan Liu. "The Challenges of Islamic Branding: Navigating Emotions and Halal.” Journal of Islamic Marketing 2, no. 1 (2011): 28-42.

Jenkins, Willis. "Islamic Law and Environmental Ethics: How Jurisprudence (Ushûl Al-Fiqh) Mobilizes Practical Reform.” Worldviews: Global Religions, Culture, and Ecology 9, no. 3 (2005): 338-364. 
Khallaf, Abdul Wahhab. Ushûl al-Fiqh. Kuwait: Dar al-Qalam, 1978.

Kuhn, Thomas S. The Structure of Scientific Revolution. Chicago: The University of Chicago Press, 1970.

Mahfudz, Asmawi. Pembaruan Hukum Islam. Yogyakarta: Teras, 2010 Minhaji, Akh. Sejarah Sosial dalam Studi Islam: Teori, Metodologi dan Implementasi. Yogyakarta: SUKA Press, 2013.

Muqoyyidin, Andik Wahyun. "Membangun Kesadaran Inklusif-Multikultural untuk Deradikalisasi Pendidikan Islam.” Jurnal Pendidikan Islam 2, no. 1 (2012).

Najib, Agus Moh. Pengembangan Metodologi Fikih Indonesia dan Kontribusinya bagi Pembentukan Hukum Nasional. Jakarta: Kementerian Agama RI, 2011.

Naim, Ngainun. "Membangun Kerukunan Masyarakat Multikultural." Harmoni 15, no. 1 (2016): 203-213.

Qomar, Mujamil. Epistemologi Pendidikan Islam, dari Metode Rasional hingga Metode Kritik. Jakarta: Erlangga, 2006.

. Tradisi-Tradisi Kreatif Pemikiran Islam Indonesia. Tulungagung: IAIN Tulungagung Press, 2015.

Rahmatullah, Lutf. "Eksistensi Hukum Islam di Tengah Keragaman Budaya Indonesia (Perspektif Baru Sejarah Hukum Islam dalam Bingkai Dialektika Nilai-nilai Syari'ah dan Budaya)." Al-Manahij: Jurnal Kajian Hukum Islam 10, no. 1 (2016): 63-82.

Raihani. Creating Multicultural Citizens: A Portrayal of Contemporary Indonesian Education. London and New York: Routledge, 2014.

Rofiq, Ahmad. Pembaharuan Hukum Islam di Indonesia. Yogyakarta: Gama Media, 2001.

Ridwan, Ahmad Hasan and Irfan Safrudin. Dasar-dasar Epistemologi Islam. Bandung: Pustaka Setia, 2011.

Sardar, Ziauddin. Jihad Intelektual, Merumuskan Parameter-Parameter Sains Islam, trans. A.E. Priyono. Surabaya: Risalah Gusti, 1998.

Saeed, Abdullah. "Ijtihad and Innovation in Neo-Modernist Islamic Thought in Indonesia." Islam and Christian-Muslim Relations 8, no. 3 (1997): 279-295. 
Sjadzali, Munawir. Polemik Reaktualisasi Ajaran Islam. Jakarta: Pustaka Panjimas, 1988. . Ijtihad Kemanusiaan. Jakarta: Paramadina, 1997.

Suharto, Toto dan Ja'far Assagaf. "Membendung Arus Paham Keagamaan Radikal di Kalangan Mahasiswa PTKIN", Jurnal Al-Tahrir 14, No. 1, (Mei 2014): 159-165.

Syatibi, Abu Ishaq al-. al-Muwafaqat fi Ushul al-Ahkam. Bayrut: Dar al-Kitab al-'Ilmiyyah, 2002.

Timur Kuran. "Islam and Underdevelopment: An Old Puzzle Revisited." Journal of Institutional and Theoretical Economics (JITE)/ Zeitschrift für die gesamte Staatswissenschaft (1997): 41-71.

Tobroni. Relasi Kemanusiaan dalam Keberagamaan (Mengembangkan Etika Sosial Melalui Pendidikan. Bandung: Karya Putra Darwati, 2012.

Udovitch, Abraham. "Islamic Law and the Social Context of Exchange in the Medieval Middle East." History and Anthropology 1, no. 2 (1985): 445-465.

Usman, Iskandar. Istihsan dan Pembaharuan Hukum Islam. Jakarta: Raja Grafindo Persada, 1994.

Wael B Hallaq. The Origins and Evolution of Islamic Law. Vol. 1. Cambridge University Press, 2005.

Wahid, Marzuki \& Rumadi. Fiqh Madzhab Negara. Yogyakarta: LKiS, 2001.

Yilmaz, Ihsan. "Ijtihad and Tajdid by Conduct." Turkish Islam and the Secular State, the Gülen Movement. Syracuse, NY: Syracuse University Press. Google Scholar (2003).

Wahyudi, Yudian. Ushul Fikih Versus Hermeneutika: Membaca Islam dari Kanada dan Amerika Yogyakarta: Pesantren Nawasea Press, 2007. . Maqâshid Syari'ah dalam Pergumulan Politik: Berfilsafat Hukum Islam dari Harvard ke Sunan Kalijaga. Yogyakarta: Nawesea, Pesantren Nawesea Press, 2007. 